\title{
IDENTIFIKASI SIFAT MORFOLOGI DAN FISIOLOGI ISOLAT BAKTERI BLOOD DISEASE BACTERIA (BDB) PADA BIBIT PISANG (MUSA SP) AMBON HIJAU
}

\author{
Darmansyah $^{1}$ dan Yefriwati ${ }^{1}$ \\ ${ }^{1}$ Program Studi Hortikultura, Politeknik Pertanian Negeri Payakumbuh \\ Jl. Raya Negara Km. 7 Tanjung Pati, 26271, Payakumbuh \\ Korespondensi:yefriwati@ymail.com
}

$\begin{array}{ll}\text { Diterima } & : 05 \text { Maret } 2018 \\ \text { Disetujui } & : 29 \text { Maret } 2018 \\ \text { Diterbitkan } & : 15 \text { Juli } 2018\end{array}$

\begin{abstract}
ABSTRAK
Pisang (Musa sp) merupakan salah satu jenis buah tropika yang mempunyai potensi cukup tinggi untuk dikelola secara intensif dengan berorientasi agribisnis, karena pisang telah menjadi usaha dagang ekspor dan impor di pasar Internasional. Akhir-akhir ini tanaman pisang banyak terserang penyakit layu bakteri, untuk mengatasi permasalahan ini maka digunakan teknologi Fungi Mikoriza Arbuskular (FMA). FMA merupakan suatu bentuk hubungan simbiosis mutualisme dengan akar tanaman yang dapat mengendalikan serangan penyakit. Tujuan penelitian ini adalah mengidentifikasi sifat morfologi dan fisiologi isolat bakteri Blood Disease Bacteria (BDB) Pada Bibit Pisang. Penelitian ini telah dilaksanakan di laboratorium Biologi Politeknik Pertanian Negeri Payakumbuh, mulai dari bulan Mei sampai Juli 2017. Parameter yang diamati adalah (1) sifat morfologi koloni bakteri BDB (ukuran, bentuk, permukaan), (2) sifat fisiologi bakteri BDB (uji gram, uji pektinase). Berdasarkan hasil identifikasi sifat morfologi bakteri BDB di laboratorium terlihat bentuk koloni bulat, bentuk sel batang, warna koloni putih dengan formasi kuning dan ukuran koloni 0,5 - 4,5 um. Sedangkan sifat fisiologi dari bakteri BDB ini adalah gram positif dan enzim pektinase.
\end{abstract}

Keywords: Fungi Mikoriza Arbuskular (FMA), Blood Disease Bacteria

\begin{abstract}
Banana (Musa sp) representing one of the tropical fruit type which have high potency enough to be managed intensively with orienting agribisnis, because banana have come to the effort trade export and import [in] International market. Recently banana crop come down with many bacterium wilting, to overcome this problems hence used by technology of Fungi Mikoriza Arbuskular (FMA). FMA represent a[n symbiosis form of mutualisme with crop root able to control disease attack. Target of this research [is] to identify the nature of physiology and morphology of isolat bacterium of Blood Disease Bacteria (BDB) at Seed Banana.This research have been executed in Polytechnic Biological laboratory Agriculture of Country of Payakumbuh, start from April until July 2017. Parameter perceived [by] [is] (1) nature of bacterium colony morphology of BDB
\end{abstract}


(size measure, form, surface), (2) nature of bacterium physiology of BDB (gram test, test pektinase). Pursuant to result identify the nature of bacterium morphology of BDB in laboratory seen circular colony form, bar cell form, white colony colour with formation turn yellow and colony size measure 0,5 - 4,5 um. While nature of physiology of bacterium of $B D B$ this is positive gram and enzyme of pektinase.

\section{Keywords: Fungi Mykoriza Arbuscular (FMA), Blood Disease Bacteria}

\section{PENDAHULUAN}

Pisang (Musa sp) merupakan salah satu jenis buah tropika yang mempunyai potensi cukup tinggi untuk dikelola secara intensif dengan berorientasi agribisnis, karena pisang telah menjadi usaha dagang ekspor dan impor di pasar Internasional (Rukmana, 2000). Pisang memiliki banyak keunggulan yaitu produktivitas yang tinggi, nilai gizi dan ragam genetika yang tinggi, adaptif pada ekosistem yang luas, biaya produksi yang rendah dan diterima oleh masyarakat (Sulyo, 1992).

Berdasarkan proyeksi peningkatan jumlah penduduk dari 220-230 juta diperkirakan kebutuhan konsumsi segar dalam negeri akan mencapai 1,8 - 2,3 juta ton dan tingkat konsumsi produk olahnya dari tahun 2005 sampai 2010 diperkirakan akan meningkatkan dari 8,2 - 10 kg/kapita/tahun (Anonim, 2005). Proyeksi kebutuhan pisang tersebut sebagai produk olahan mulai tahun 2005-2010 mencapai 90.000 ton. Volume tersebut memerlukan areal pertanaman seluas 6000 ha pada tahun 2010, dimana 4500 ha sudah tersedia tetapi belum dikelola secara intensif, sedangkan 1500 ha akan dilakukan pembukaan lahan baru (Anonim, 2005). Secara nasional produksi pisang masih rendah (11.60-16.30 ton ha-1) dibandingkan potensi produksi yang dapat mencapai 20-60 ton ha-1, bahkan untuk kultivar group Cavendish ada yang bias mencapai 100 ton ha-1 (Verheij dan Coronel (1992) cit Tutik Setyawati (1996). Terjadinya kecendrungan penurunan produktivitas pisang sejak tahun 1995 (13.58 ton ha-1) menjadi 12.51 ton ha1 (7.88\%) (FAOSTAT, 2005 cit Anonim, 2005).

Penyebab utama turunnya produksi pisang adalah penyakit darah bakteri yang disebabkan oleh Blood Disease Bacteria (BDB). Penyakit ini bersifat sistemik, sangat berbahaya karena dapat mematikan tanaman (Sulyo, 1992). Penyakit darah bakteri menempati urutan pertama dalam daftar penyakit pisang di Indonesia (Hermanto, Habazar, Rivai, 2000). 


\section{I.UMIBUNG}

Penyakit darah bakteri ini sulit dikendalikan karena patogen penyebabnya dapat bertahan paling kurang satu tahun di dalam tanah tanpa kehilangan virulensinya (Semangun, 1989; Wardlaw, 1972, Sulyo, 1992). Oleh karena itu perlu dilakukan identifikasi terhadap sifat morfologi dan fisiologi penyakit darah bakteri.

Berdasarkan hal diatas penulis telah melakukan penelitian dengan judul Identifikasi Sifat Morfologi Dan Fisiologi Penyakit Darah Bakteri Blood Disease BacteriaPada Bibit Pisang.

\section{METODE PENELITIAN}

Penelitian ini telah dilaksanakan di Laboratorium Politeknik Pertanian Negeri Payakumbuh, yang dimulai dari bulan Mei 2017 sampai Juli 2017. Bahan yang digunakan dalam penelitian ini adalah media TZC, biakan murni bakteri BDB, kutek bening, akuades, allumunium foil, asam laktat.

Alat yang digunakan adalah autoclave, laminar air flow, rotary evaporator, shaker, cawan Petri, micropipet $20 \mu \mathrm{l}$, colony counter, pinset, pinset spora, bunsen, gelas piala, pipet ukur volume $20 \mathrm{ml}$, corong pisah, hot plate (IEC (R), mikroskop binokuler, mikroskop disecting, oven, pinset spora, timbangan analitik.

Metode pelaksanaan dilakukan secara langsung yaitu setelah bakteri BDB diisolasi pada media NA, kemudian dilakukan identifikasi sifat morfologi dan fisiologi bakteri Blood Disease Bacteria (BDB) yaitu ;

\section{Sifat morfologi koloni}

Pengamatan morfologi koloni bakteri BDB pada medium TZC yang berumur 3 hari setelah inkubasi meliputi bentuk, ukuran pinggiran, warna, bentuk permukaan.

\section{Sifat fisiologi}

\subsection{Reaksi Gram}

Pengujian reaksi Gram bertujuan untuk mengetahui sifat bakteri tergolong gram negatif atau positif. Pengujian ini menggunakan metoda Sand et al., 1990). Larutan $\mathrm{KOH} 3 \%$ diteteskan pada gelas objek, kemudian diambil satu koloni bakteri dengan jarum ose dan diaduk secara merata.

2.2 Uji pektinase

Pengujian pektinase bertujuan untuk mengetahui isolat bakteri yang menghasilkan enzim pektinase. Uji ini menggunakan metoda Schaad (1988), bahan 
yang digunakan adalah potongan kentang setebal $1 \mathrm{~cm}$, kemudian disterilkan permukaannya dengan alkohol $70 \%$ dan dibilas dengan akuades steril. Irisan kentang kemudian diletakkan dalam cawan petri yang dilapisi kertas saring lembab dan diinokulasi dengan satu ose koloni bakteri dan diinokubasikan selama 72 jam.

\subsection{Uji Patogenisitas reaksi hipersensitif}

Uji ini menggunakan metoda Klement et al., (1990) bertujuan mengetahui daya patogenisitas isolat bakteri pada dauntembakau. Suspensi bakteri dengan kerapatan 108 berdasarkan skala Mc Farland (1987) dalam Klement et al., (1990), diinfiltrasikan pada permukaan bawah daun tembakau sampai jenuh. Sebagai kontrol daun diinfiltrasikan dengan akuades steril. 15

\subsection{Patogenisitas pada bibit pisang}

Sumber inokulum patogen diperoleh dari suspensi buah yang terinfeksi, dengan cara menyiramkan $20 \mathrm{ml}$ suspensi bakteri pada ujung akar yang telah dilukai pada tanaman pisang berumur 2 bulan. Tanaman yang diinokulasikan disungkup dengan kantong plastik dan diinkubasi di rumah kawat. Patogenisitas isolat ditandai dengan kemampuan bakteri yang menimbulkan penyakit berupa klorosis, penguningan dan layu daun.

\section{Parameter Pengamatan}

1. Sifat Morfologi Koloni Bakteri BDB

2. Sifat Fisiologi Koloni Bakteri BDB
a. Uji Gram
b. Uji Peptinase
c. Uji Patogenisitas reaksi hipersensitif
d. Uji Patogenisitas pada bibit pisang

\section{HASIL DAN PEMBAHASAN}

\section{Sifat morfologi koloni bakteri BDB}

Berdasarkan hasil pengamatan terhadap morfologi koloni bakteri BDB terlihat bahwa bentuk koloni bulat, bentuk sel batang, warna koloni putih dengan formasi kuning dan ukuran koloni $0,5-4,5$ um. 


\section{Sifat fisiologi koloni bakteri BDB}

\section{Reaksi gram}

Pengujian reaksi gram bertujuan untuk mengetahui sifat bakteri tergolong gram positif atau negatif. Dari hasil pengujian menunjukkan terjadinya pengumpalan, maka bakteri ini tergolong gram negatif.

\section{Uji pektinase}

Pengujian ini bertujuan untuk mengetahui isolat bakteri yang menghasilkan enzim pektinase. Dari hasil pengujian menunjukkan bahwa pada bagian kentang yang diinokolasikan bakteri BDB terjadi perubahan warna menjadi coklat kehitaman dan pembusukan, menunjukkan bahwa bakteri bersifat positif yang menghasilkan enzim pektinase.

\section{Uji Patogenisitas Reaksi Hipersensitif}

Hasil pengujian patogenisitas reaksi hipersensitif pada daun tembakau yang diinfiltrasi dengan suspensi bakteri BDB menunjukkan terjadinya nekrosis pada permukaan daun tembakau.

\section{Uji Patogenisitas pada Bibit Pisang}

Hasil pengujian patogenisitas pada bibit pisang berumur dua bulan yang telah diinokulasi bakteri BDB menunjukkan gejala nekrotik pada daun, penguningan dan layu.

\section{KESIMPULAN}

Morfologi koloni bakteri BDB terlihat bahwa bentuk koloni bulat, bentuk sel batang, warna koloni putih dengan formasi kuning dan ukuran koloni 0,5-4,5 um. Sifat fisiologis bakteri BDB tergolong gram negatif. Pengujian pada bagian kentang yang diinokolasikan bakteri BDB terjadi perubahan warna menjadi coklat kehitaman dan pembusukan, menunjukkan bahwa bakteri bersifat positif yang menghasilkan enzim pektinase. Pengujian patogenisitas reaksi hipersensitif pada daun tembakau yang diinfiltrasi dengan suspensi bakteri BDB menunjukkan terjadinya nekrosis pada permukaan daun tembakau. Pengujian patogenisitas pada bibit pisang berumur dua bulan yang telah diinokulasi bakteri BDB menunjukkan gejala nekrotik pada daun, penguningan dan layu. 


\section{REFERENSI}

Ahmad, F. 1980. Dasar-dasar ilmu tanah. Proyek peningkatan dan pengembangan perguruan tinggi Universitas Andalas Padang.

Badan Pusat Statistik. 2003. Statistik Indonesia. Jakarta.

Baharuddin, B. 1994. Pathological, Biochemical and Serological Characterization of the Blood Disease Bacterium Affecting Banana and Plantain (Musa sp).In Indonesia. Cuvillier verlag gettingen. 129 pp.

Balai Penelitian Tanaman Buah. 2003. Komoditas pisang. Departemen penelitian tanaman buah. Solok.

Brundrett, M., Abbot, L. K. Jasper, D.A and Aswath, N. 1994. Mycorrhizal association in Disturbed and Natural Habitats in Tropical Australia Mycorrhizas for plantation Forestry in Asia. Proceeding of International Symposium and workshop, Kaping, Guandong Province, P.R. China 7-11 November 1994. Editors M.Brundrett, B.dell. Maljczuk and Gong Mingqin. P.34-40.

Daryanto. 2002. Langkah Penanggulangan Penyakit Layu Pisang di Indonesia. Makalah disampaikan pada Seminar Nasional Penyakit Layu Pisang di Padang tanggal 2223 Oktober.

Djatnika, I. 2000. Penyakit Umum Pada Pisang. Balai Penelitian Tanaman Buah Solok. 15 hal.

Desfitri, A. 2005. Pengujian isolat indigenous Cendawan Mikoriza Arbuskular pada bibit pisang terhadap Rodpholus similis Cobb. Skripsi. Fakultas Pertanian. Universitas Andalas. Padang.

Ekamawati, Hanna Astuti. 1989. Mekanisme angkutan nutrien dalam simbiosis mikoriza arbuskular. Dalam worshop aplikasi cendawan mikoriza arbuskular pada tanaman pertanian, perkebunan, perkembangan, dan kehutanan. Asosiasi Mikoriza Indonesia. Bogor. pp 77-84

Habazar, T dan Rivai, F. 2000. Dasar-Dasar Bakteri Patogenik Tumbuhan. Fakultas Pertanian. Universitas Andalas. Padang.

Yefriwati et al., 2004. Aplikasi Cendawan Mikoriza Dalam Mengendalikan Penyakit Layu Bakteri (Ralstonia solanacearum ras 2) 